\title{
Prognostic and predictive value of VHL gene alteration in renal cell carcinoma: a meta-analysis and review
}

\author{
Bum Jun Kim ${ }^{1}$, Jung Han Kim ${ }^{1}$, Hyeong Su Kim ${ }^{1}$, Dae Young Zang ${ }^{1}$ \\ ${ }^{1}$ Division of Hemato-Oncology, Department of Internal Medicine, Hallym University Medical Center, Hallym University College \\ of Medicine, Seoul 07441, Republic of Korea \\ Correspondences to: Jung Han Kim, email: harricil@hotmail.com, harricil@hallym.or.kr \\ Keywords: renal cell carcinoma, von Hippel-Lindau, anti-VEGF therapy, prognosis, meta-analysis \\ Received: October 15, $2016 \quad$ Accepted: December 28, $2016 \quad$ Published: January 17, 2017
}

\section{ABSTRACT}

The von Hippel-Lindau ( $\mathrm{VHL}$ ) gene is often inactivated in sporadic renal cell carcinoma (RCC) by mutation or promoter hypermethylation. The prognostic or predictive value of VHL gene alteration is not well established. We conducted this metaanalysis to evaluate the association between the VHL alteration and clinical outcomes in patients with RCC. We searched PUBMED, MEDLINE and EMBASE for articles including following terms in their titles, abstracts, or keywords: 'kidney or renal', 'carcinoma or cancer or neoplasm or malignancy', 'von Hippel-Lindau or VHL', 'alteration or mutation or methylation', and 'prognostic or predictive'. There were six studies fulfilling inclusion criteria and a total of $\mathbf{6 3 3}$ patients with clear cell RCC were included in the study: 244 patients who received anti-vascular endothelial growth factor (VEGF) therapy in the predictive value analysis and 419 in the prognostic value analysis. Out of 663 patients, $410(61.8 \%)$ had VHL alteration. The meta-analysis showed no association between the VHL gene alteration and overall response rate (relative risk $=1.47$ [95\% CI, 0.81-2.67], $\mathrm{P}=0.20$ ) or progression free survival (hazard ratio $=1.02[95 \% \mathrm{CI}$, $0.72-1.44], P=0.91)$ in patients with $R C C$ who received VEGF-targeted therapy. There was also no correlation between the VHL alteration and overall survival ( $H R=0.80$ [95\% CI, 0.56-1.14], $\mathrm{P}=0.21$ ). In conclusion, this meta-analysis indicates that VHL gene alteration has no prognostic or predictive value in patients with clear cell RCC.

\section{INTRODUCTION}

Renal cell carcinoma (RCC) is the most common kidney cancer [1], and approximately 63,000 and 5,000 new cases of kidney cancer are diagnosed each year in the United States and Korea [2, 3]. Although complete surgical resection is considered to be curative treatment option at early stage, about $50 \%$ of patients experience disease recurrence after curative resection and up to $30 \%$ of patients have metastases at the time of the initial diagnosis [4].

The von Hippel-Lindau (VHL) gene is a tumor suppressor gene and VHL gene alteration occurs in 50-70\% of clear cell RCC $[5,6]$. VHL gene has an important role in regulation of the hypoxia pathway via the hypoxia inducible factors (HIFs) in sporadic RCC [7]. Functional loss of VHL protein which is induced from VHL gene alteration allows HIFs to act as a transcription factor of various pro-tumorigenic genes including vascular endothelial growth factor (VEGF) and subsequently leads to RCC development and progression by inducing angiogenesis [8].

Many therapeutic approaches to target this molecular pathway have been investigated in RCC patients and various VEGF-targeted agents yielded successful results [9-13]. Although VHL gene alteration plays a key role in RCC pathogenesis and provides plausible therapeutic target for anti-VEGF therapy, the clinical significance of VHL gene alteration in RCC has not been well established. We conducted this meta-analysis of previously published studies to investigate the predictive and prognostic value of VHL gene alteration in patients with RCC.

\section{RESULTS}

Results of search and eligible studies

Figure 1 is the flowchart of studies assessed through the searching process. Based on our searching 
criteria, 22 studies were retrieved for detailed evaluation. Among them, 16 studies missed survival outcomes and were excluded from the study. Finally, the remaining 6 studies [14-19] fulfilled our inclusion criteria and were included in the meta-analysis. Three studies [14-16] with 244 patients were analyzed to investigate if VHL gene alteration acts as a predictive biomarker of VEGF-targeted therapy and the other 3 studies [17-19] with 419 patients were included in the survival analysis. All patients included in the six studies had clear cell RCC.

\section{VHL alteration}

The incidence of VHL gene alteration was various from $57 \%$ to $90 \%$ among the six studies. Out of a total of 663 patients, $410(61.8 \%)$ had VHL alteration. Four studies [15-18] also provided the data of 'loss of function (LOF)' mutation and the rate of LOF mutation ranged from $38 \%$ to $58 \%$.

\section{VHL gene alteration and outcomes to VEGF- targeted therapy}

Table 1 lists 3 studies included in the predictive marker analysis. One [14] was a prospective randomized phase II study and the other two $[15,16]$ were retrospective studies. While various VEGF-targeted agents including sunitinib, sorafenib, bevacizumab, and axitinib were used in two retrospective studies $[15,16]$, pazopanib was used in the prospective study [14].

These studies investigated the clinical impact of VHL alteration on the efficacy of VEGF- targeted therapy in patients with metastatic RCC. When patients with VHL gene alterations compared with the wild-type patients, the pooled relative risk (RR) for overall response rate (ORR) was 1.47 [95\% confidence interval (CI), 0.81-2.67], with no statistical significance $(\mathrm{P}=0.20)$ (Figure 2A).

We also calculated hazard ratio (HR) and 95\% CI for progression-free survival (PFS) by analyzing Kaplan-Meier curves of the studies. As shown in Figure $2 \mathrm{~B}$, there was no significant association between the VHL gene alteration and PFS to VEGF targeted therapy in patients with metastatic RCC $(\mathrm{HR}=1.02$ [95\% CI, $0.72-1.44], \mathrm{P}=0.91)$. The results had no evidence of heterogeneity.

\section{VHL gene alteration and overall survival}

Table 2 shows 3 studies included in the prognostic marker analysis. We pooled the survival data from the studies to evaluate the association of VHL alteration and overall survival (OS) in patients with metastatic RCC. Two studies $[17,18]$ directly presented HR and 95\% CI

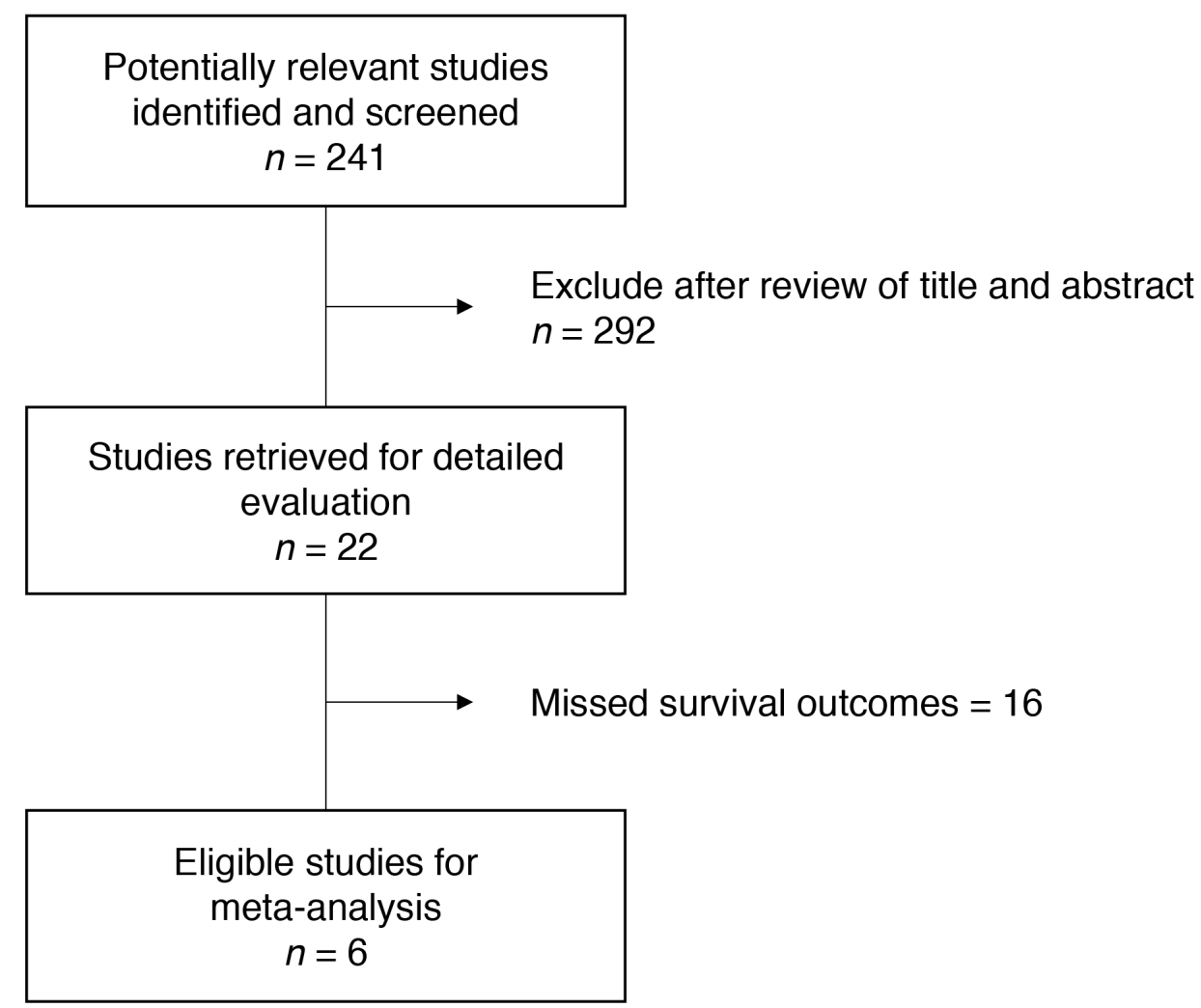

Figure 1: Flow diagram of searching process. 
Table 1: Summary of three studies evaluating the impact of VHL alteration on the efficacy of VEGF-targeted therapy in RCC

\begin{tabular}{|c|c|c|c|c|c|c|c|c|c|c|}
\hline Study & $\begin{array}{c}\text { Histological } \\
\text { subtype }\end{array}$ & $\begin{array}{c}\text { Alteration } \\
\text { analysis }\end{array}$ & $\mathbf{N}$ & $\begin{array}{r}\text { VHL statu } \\
\text { (LOF } \\
\text { hyperm }\end{array}$ & $\begin{array}{l}\text { [all mutation } \\
\text { utation)/ } \\
\text { thylation)] }\end{array}$ & $\begin{array}{c}\text { VEGF- } \\
\text { targeted } \\
\text { agents used }\end{array}$ & $\begin{array}{c}\text { ORR } \\
(\%)\end{array}$ & $\begin{array}{c}\text { RR for ORR } \\
(95 \% \mathrm{CI})\end{array}$ & $\begin{array}{c}\text { PFS } \\
\text { (months) }\end{array}$ & $\begin{array}{c}\text { HR for PFS } \\
(95 \% \text { CI })\end{array}$ \\
\hline \multirow[t]{2}{*}{$\begin{array}{l}\text { Choueiri } \\
\text { et al.(2013) }\end{array}$} & $\mathrm{ccRCC}$ & PCR & 78 & $\begin{array}{c}\text { VHL } \\
\text { alteration }\end{array}$ & $70[68(\mathrm{NA}) / 8]$ & Pazopanib & 41.4 & $\begin{array}{c}1.18 \\
(0.26-5.33)\end{array}$ & 17.4 (median) & $\begin{array}{c}0.69 \\
(0.16-3.06)\end{array}$ \\
\hline & & & & Wild type & 8 & & 37.5 & & 13.8 (median) & \\
\hline \multirow[t]{2}{*}{$\begin{array}{l}\text { Choueiri } \\
\text { et al. } \\
\text { (2008) }\end{array}$} & $\mathrm{ccRCC}$ & PCR & 123 & $\begin{array}{c}\text { VHL } \\
\text { alteration }\end{array}$ & $\begin{array}{c}72 \\
{[60(47) / 12]}\end{array}$ & $\begin{array}{c}\text { Sunitinib, } \\
\text { Sorafenib, } \\
\text { Bevacizumab, } \\
\text { Axitinib }\end{array}$ & 49.3 & $\begin{array}{c}1.48 \\
(0.69-3.14)\end{array}$ & NA & $\begin{array}{c}1.15 \\
(0.76-1.74)\end{array}$ \\
\hline & & & & Wild type & 51 & & 31.4 & & NA & \\
\hline \multirow[t]{2}{*}{$\begin{array}{l}\text { Rini } \\
\text { et al.(2006) }\end{array}$} & & PCR & 43 & $\begin{array}{c}\text { VHL } \\
\text { alteration }\end{array}$ & $26[25(18) / 1]$ & $\begin{array}{c}\text { Sunitinib } \\
\text { Axitinib } \\
\text { Interferon } \alpha+ \\
\text { bevacizumab }\end{array}$ & 48 & $\begin{array}{c}1.69 \\
(0.48-6.00)\end{array}$ & 10.8 (median) & $\begin{array}{c}0.80 \\
(0.40-1.56)\end{array}$ \\
\hline & & & & Wild type & 17 & & 35 & & 5.5 (median) & \\
\hline
\end{tabular}

VHL, von Hippel-Lindau; LOF, loss of function; VEGF, vascular endothelial growth factor; ORR, overall response rate; RR, relative risk; PFS, progression-free survival; HR, hazard ratio; ccRCC, clear cell renal cell carcinoma; PCR, polymerase chain reaction; NA, not available

for OS. In the remaining one study [19], we calculated HR and $95 \%$ CI by analyzing Kaplan-Meier curve. As shown in Figure 3, there was no significant association between the VHL alteration and $\mathrm{OS}(\mathrm{HR}=0.80[95 \% \mathrm{CI}$, $0.56-1.14], \mathrm{P}=0.21$ ), with no heterogeneity between the studies.

\section{DISCUSSION}

VHL gene has an important role in regulation of the hypoxia pathway via the HIFs in sporadic RCC [7]. With functional loss of VHL protein, HIFs can act as a transcription factor of various pro-tumorigenic genes

A

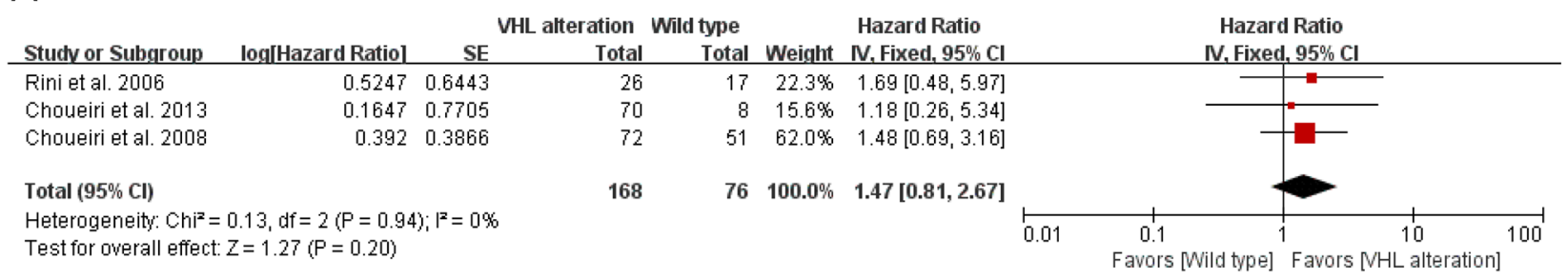

B

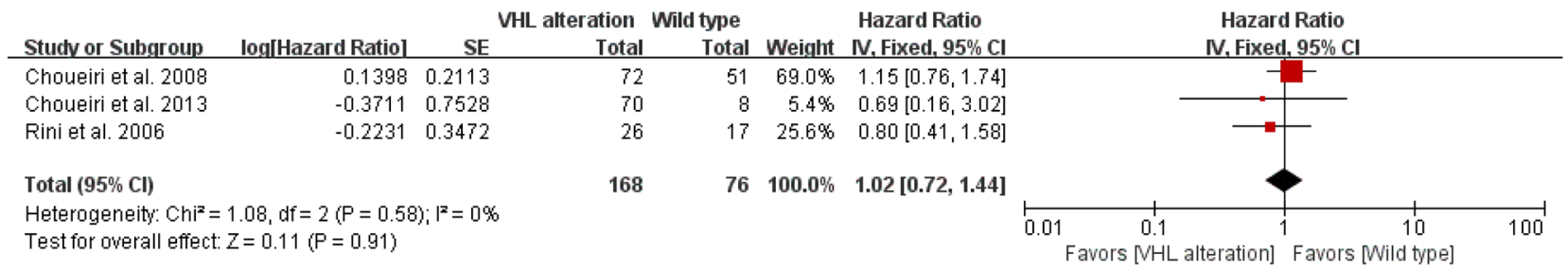

Figure 2: Forest plots for the association between VHL gene alteration and outcomes of VEGF-targeted therapy. A. The relation between VHL gene alteration and overall response rate to VEGF-targeted therapy. B. The relation between VHL gene alteration and progression-free survival to VEGF-targeted therapy. 
Table 2: Summary of three studies evaluating the association between VHL alteration and prognosis in RCC

\begin{tabular}{|c|c|c|c|c|c|c|c|c|c|}
\hline & $\begin{array}{c}\text { Histologic } \\
\text { subtype }\end{array}$ & $\begin{array}{c}\text { Alteration } \\
\text { Analysis }\end{array}$ & $\mathbf{N}$ & $\begin{array}{r}\text { VHI } \\
\text { [all n } \\
\text { (LOF I } \\
\text { hyperm }\end{array}$ & $\begin{array}{l}\text { status } \\
\text { iutation } \\
\text { nutation)/ } \\
\text { thylation)] }\end{array}$ & $\begin{array}{c}\text { RFS } \\
\text { (months) }\end{array}$ & $\begin{array}{l}\text { HR for } \\
\text { RFS (95\% } \\
\text { CI) }\end{array}$ & OS & $\begin{array}{l}\text { HR for OS } \\
(95 \% \mathrm{CI})\end{array}$ \\
\hline \multirow[t]{2}{*}{$\begin{array}{l}\text { Smits et } \\
\text { al. (2008) }\end{array}$} & ccRCC & $\mathrm{PCR}+\mathrm{DS}$ & 185 & $\begin{array}{c}\text { VHL } \\
\text { alteration }\end{array}$ & $\begin{array}{c}106 \\
{[100(97) / 16]}\end{array}$ & NA & NA & NA & $\begin{array}{c}1.08(0.69- \\
1.68)\end{array}$ \\
\hline & & & & Wild type & 79 & NA & NA & NA & \\
\hline \multirow[t]{2}{*}{$\begin{array}{l}\text { Patard et } \\
\text { al. (2008) }\end{array}$} & ccRCC & PCR & 100 & $\begin{array}{c}\text { VHL } \\
\text { alteration }\end{array}$ & $\begin{array}{c}58[58(58) / \\
\text { NA }]\end{array}$ & NA & NA & $\begin{array}{c}\text { 2-year } \\
\text { RCC-SS: } \\
84 \%\end{array}$ & $\begin{array}{c}0.53(0.25- \\
1.09)\end{array}$ \\
\hline & & & & Wild type & 42 & NA & NA & $\begin{array}{c}\text { 2-year } \\
\text { RCC-SS: } \\
61 \%\end{array}$ & \\
\hline \multirow[t]{2}{*}{$\begin{array}{l}\text { Yao et al. } \\
(2002)\end{array}$} & ccRCC & $\begin{array}{c}\text { DNA- } \\
\text { SSCP+DS }\end{array}$ & 134 & $\begin{array}{c}\text { VHL } \\
\text { alteration }\end{array}$ & 78 [NA/NA] & $\begin{array}{c}138 \\
\text { (median) }\end{array}$ & $\begin{array}{c}0.40(0.18- \\
0.91)\end{array}$ & $\begin{array}{c}144 \\
\text { months } \\
\text { (median) }\end{array}$ & $\begin{array}{c}0.36(0.13- \\
0.97)\end{array}$ \\
\hline & & & & Wild type & 56 & $\begin{array}{c}116 \\
\text { (median) }\end{array}$ & & $\begin{array}{c}125 \\
\text { months } \\
\text { (median) }\end{array}$ & \\
\hline
\end{tabular}

VHL, von Hippel-Lindau; LOF, loss of function; RFS, relapse-free survival; HR, hazard ratio; OS, overall survival; ccRCC, clear cell renal cell carcinoma; RCC-SS, renal cell cancer-specific survival; PCR, polymerase chain reaction; DS, direct sequencing; DNA-SSCP, DNA-single-strand conformation polymorphism; NA, not available

including VEGF [8]. VHL alteration also provides therapeutic target for anti-angiogenic treatment [9-13]. Therefore, it is logical to assume that VHL gene alteration might have important implications for disease prognosis. Brauch et al. reported that the presence of VHL mutation or hypermethylation correlated significantly with a poor risk factor (pT3 tumor grade) [20]. However, the role of VHL alteration as a prognostic factor was controversial in patients with RCC [17-19, 21, 22]. In this study, we explored if the VHL gene alteration was associated with outcomes to VEGF-targeted therapy and OS. The metaanalysis of six relevant studies showed no association between the VHL alteration and ORR or PFS to VEGF- targeted agents in patients with clear cell RCC. There was also no correlation between the VHL alteration and OS.

In this study with a total of 663 patients, 410 $(61.8 \%)$ had VHL alteration. VHL gene alteration is a broad concept of genetic abnormality which includes VHL gene mutation, promoter hypermethylation, and loss of heterozygosity. These various types of VHL gene alteration can be divided into 'LOF' mutation which leads to truncated VHL proteins and DNA sequence variants of unknown biological consequence. Interestingly, several studies reported that the LOF mutation rather than other types of VHL alteration showed meaningful relationship with survival outcome and response to VEGF-targeted

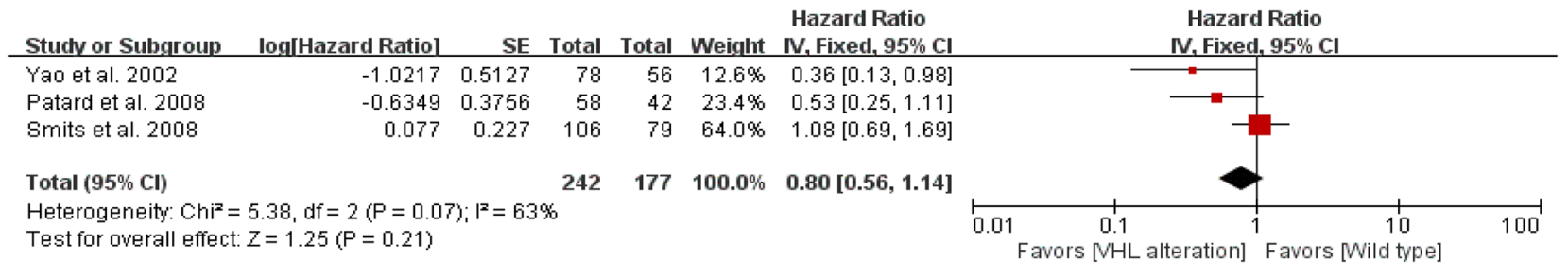

Figure 3: Forest plot for the association between VHL gene alteration and overall survival. 
therapy in patients with RCC [15-17,20,21]. LOF mutation acted as a good predictive marker with better response rate and prolonged time to progression in RCC patients who received VEGF-targeted therapy $[15,16]$. Other studies showed that LOF mutation of VHL gene was significantly associated with poor survival outcome [23, 24]. In this meta-analysis, the rate of LOF mutation ranged from $38 \%$ to $58 \%$. Because VHL gene alteration was not classified into subgroups in most studies, however, we could not evaluate the role of LOF mutation as a predictive or prognostic marker

Recently, a number of studies have been conducted to identify molecular prognostic factors in metastatic RCC. The whole exome sequencing identified at least 19 significantly mutated genes in clear cell RCC, including VHL, PBRM1, SETD2, KDM5C, PTEN, BAP1, mTOR, and TP53 [25]. These mutated genes may serve as potential prognostic markers and are now under investigation. One study reported that clear cell RCC patients with BAP1 mutation showed poor prognosis, compared to those with BRM1 mutation [26]. Since the approval of VEGF-targeted agents, significant efforts have been undertaken to discover useful and clinically relevant biomarkers to predict the outcomes to antiVEGF therapy [27-32], but no biomarkers are ready for routine clinical use. In one study examining the pharmacokinetics of sunitinib, an A-allele in CYP3A5, an absence of CAT copy in NR113 haplotype and TCG copy in ABCB1 were all predictive of improved PFS or OS and are regarded as potentially meaningful biomarkers [33].

This study has several limitations. First, the small number of studies was included in the meta-analysis and patients were treated with no identical modality. Second, this study inevitably has inherent selection bias due to the retrospective nature of included studies. Lastly, because VHL gene alteration was not classified into subgroups in most studies, we could not determine if LOF mutation has predictive or prognostic value in RCC patients.

In conclusion, this meta-analysis demonstrates that VHL gene alteration is not associated with outcomes to VEGF-targeted therapy and OS in patients with clear cell RCC. However, further studies are needed to reveal the predictive or prognostic role of certain subtypes of VHL gene alteration in patients with RCC.

\section{MATERIALS AND METHODS}

\section{Searching strategy}

A systematic search of PUBMED, MEDLINE, and EMBASE was performed (up to September 2016). The following searching terms were used: 'kidney or renal', 'carcinoma or cancer or neoplasm or malignancy', 'von Hippel-Lindau or VHL', 'alteration or mutation or methylation', 'prognostic or predictive', 'VEGF-targeted'. All eligible studies were retrieved and their bibliographies were checked for other relevant publications.

Studies that met the following inclusion criteria were included in the meta-analysis: all patients were diagnosed with histologically confirmed RCC; data on survival or treatment outcomes to VEGF-targeted therapy in association with VHL gene alteration were available; HRs for time-dependent end-points and RR for response rates were presented or could be calculated from the data.

\section{Data extraction}

Data extraction was done independently by two authors (BJK and JHK). If these two authors could not reach a consensus, another author was consulted to resolve the dispute. The following data were carefully extracted from all eligible studies: first author's name, year of publication, number of patients, histologic subtype of RCC, alteration status of VHL gene, VEGF-targeted agents used, ORR to anti-VEGF therapy, RR for ORR and PFS stratified by VHL alteration, and HR with $95 \% \mathrm{CI}$ for PFS and OS.

\section{Statistical analysis}

The association between VHL gene alteration and survival outcome was presented as HR with 95\% CI. The correlation between VHL gene alteration and ORR to VEGF-targeted therapy was expressed as RR. HR, $\mathrm{RR}$, and their respective $95 \%$ CI were obtained directly or indirectly from the original article. If the HR and 95\% CI were not presented, we calculated them with the published methods [34, 35]. Engauge digitizer version 9.1 was used to read and analyze the Kaplan-Meier curves of the included studies. A fixed effect model was used to calculate the pooled HR estimate. HRs for death were combined using an inverse variance method based on a logarithmic conversion; $95 \% \mathrm{CI}$ was used to determine the standard error (SE) using the formula $\mathrm{SE}=95 \% \mathrm{CI} / 1.96$. Heterogeneity between studies was estimated using the $I^{2}$ inconsistency test and chi-square-based Cochran's $Q$ statistic test [36] in which $P<0.05$ is taken to indicate the presence of significant heterogeneity. The Z-test for overall effect and its two-sided P-value were also assessed. RevMan version 5.2 software was used to report outcomes.

\section{ACKNOWLEDGMENTS}

This work had no specific funding.

\section{CONFLICTS OF INTEREST}

Authors declare no conflicts of interest. 


\section{REFERENCES}

1. Diaz JI, Mora LB, Hakam A. The Mainz Classification of Renal Cell Tumors. Cancer Control. 1999;6:571-9.

2. Siegel RL, Miller KD, Jemal A. Cancer statistics, 2016. CA Cancer J Clin. 2016;66:7-30.

3. Jung KW, Won YJ, Oh CM, Kong H-J, Cho H, Lee JK, Lee $\mathrm{DH}$, Lee KH. Prediction of cancer incidence and mortality in Korea, 2016. Cancer Res Treat. 2016;48:451-7.

4. Janzen NK, Kim HL, Figlin RA, Belldegrun AS. Surveillance after radical or partial nephrectomy for localized renal cell carcinoma and management of recurrent disease. Urol Clin North Am. 2003;30:843-52.

5. Richards FM. Molecular pathology of von HippelLindau disease and the VHL tumour suppressor gene. Expert Rev Mol Med. 2001;2001:1-27.

6. Gnarra JR, Duan DR, Weng Y, Humphrey JS, Chen DY, Lee S, Pause A, Dudley CF, Latif F, Kuzmin I, Schmidt L, Duh FM, Stackhouse T, et al. Molecular cloning of the von Hippel-Lindau tumor suppressor gene and its role in renal carcinoma. Biochim Biophys Acta. 1996;1242:201-10.

7. Kaelin WG Jr. The von Hippel-Lindau tumor suppressor protein and clear cell renal carcinoma. Clin Cancer Res. 2007;13:680s-684s.

8. Wiesener MS, Münchenhagen PM, Berger I, Morgan NV, Roigas J, Schwiertz A, Jürgensen JS, Gruber G, Maxwell PH, Löning SA, Frei U, Maher ER, Gröne HJ, et al. Constitutive activation of hypoxia-inducible genes related to overexpression of hypoxia-inducible factor-1alpha in clear cell renal carcinomas. Cancer Res. 2001;61:5215-22.

9. Motzer RJ, Hutson TE, Tomczak P, Michaelson MD, Bukowski RM, Rixe O, Oudard S, Negrier S, Szczylik C, Kim ST, Chen I, Bycott PW, Baum CM, et al. Sunitinib versus interferon alfa in metastatic renal-cell carcinoma. $\mathrm{N}$ Engl J Med. 2007;356:115-24.

10. Sternberg CN, Davis ID, Mardiak J, Szczylik C, Lee E, Wagstaff J, Barrios CH, Salman P, Gladkov OA, Kavina A, Zarbá JJ, Chen M, McCann L, et al. Pazopanib in locally advanced or metastatic renal cell carcinoma: results of a randomized phase III trial. J Clin Oncol. 2010;28:1061-8.

11. Motzer RJ, Hutson TE, Cella D, Reeves J, Hawkins R, Guo J, Nathan P, Staehler M, de Souza P, Merchan JR, Boleti E, Fife K, Jin J, et al. Pazopanib versus sunitinib in metastatic renal-cell carcinoma. N Engl J Med. 2013; 369:722-31.

12. Motzer RJ, Escudier B, Tomczak P, Hutson TE, Michaelson MD, Negrier S, Oudard S, Gore ME, Tarazi J, Hariharan S, Chen C, Rosbrook B, Kim S, et al. Axitinib versus sorafenib as second-line treatment for advanced renal cell carcinoma: overall survival analysis and updated results from a randomised phase 3 trial. Lancet Oncol. 2013;14: 552-62.

13. Escudier B, Pluzanska A, Koralewski P, Ravaud A, Bracarda S, Szczylik C, Chevreau C, Filipek M, Melichar B, Bajetta E, Gorbunova V, Bay J-O, Bodrogi I, et al. Bevacizumab plus interferon alfa-2a for treatment of metastatic renal cell carcinoma: a randomised, double-blind phase III trial. Lancet. 2007;370:2103-11.

14. Choueiri TK, Fay AP, Gagnon R, Lin Y, Bahamon B, Brown V, Rosenberg JE, Hutson TE, Baker-Neblett KL, Carpenter C, Liu Y, Pandite L, Signoretti S. The role of aberrant VHL/ HIF pathway elements in predicting clinical outcome to pazopanib therapy in patients with metastatic clear-cell renal cell carcinoma. Clin Cancer Res. 2013;19:5218-26.

15. Choueiri TK, Vaziri SAJ, Jaeger E, Elson P, Wood L, Bhalla IP, Small EJ, Weinberg V, Sein N, Simko J, Golshayan AR, Sercia L, Zhou M, et al. von Hippel-Lindau gene status and response to vascular endothelial growth factor targeted therapy for metastatic clear cell renal cell carcinoma. J Urol. 2008;180:860-5.

16. Rini BI, Jaeger E, Weinberg V, Sein N, Chew K, Fong K, Simko J, Small EJ, Waldman FM. Clinical response to therapy targeted at vascular endothelial growth factor in metastatic renal cell carcinoma: impact of patient characteristics and Von Hippel-Lindau gene status. BJU Int. 2006;98:756-62.

17. Smits KM, Schouten LJ, van Dijk BA, Hulsbergen-van de Kaa CA, Wouters KA, Oosterwijk E, van Engeland M, van den Brandt PA. Genetic and epigenetic alterations in the von hippel-lindau gene: the influence on renal cancer prognosis. Clin Cancer Res. 2008;14:782-7.

18. Patard JJ, Fergelot P, Karakiewicz PI, Klatte T, Trinh QD, Rioux-Leclercq N, Said JW, Belldegrun AS, Pantuck AJ. Low CAIX expression and absence of VHL gene mutation are associated with tumor aggressiveness and poor survival of clear cell renal cell carcinoma. Int $\mathrm{J}$ Cancer. 2008;123:395-400.

19. Yao M, Yoshida M, Kishida T, Nakaigawa N, Baba M, Kobayashi K, Miura T, Moriyama M, Nagashima Y, Nakatani Y, Kubota Y, Kondo K. VHL tumor suppressor gene alterations associated with good prognosis in sporadic clear-cell renal carcinoma. J Natl Cancer Inst. 2002;94:1569-75.

20. Brauch H, Weirich G, Brieger J, Glavac D, Rödl H, Eichinger M, Feurer M, Weidt E, Puranakanitstha C, Neuhaus C, Pomer S, Brenner W, Schirmacher P, et al. VHL alterations in human clear cell renal cell carcinoma: association with advanced tumor stage and a novel hot spot mutation. Cancer Res. 2000;60:1942-8.

21. Hakimi AA, Chen YB, Wren J, Gonen M, Abdel-Wahab O, Heguy A, Liu H, Takeda S, Tickoo SK, Reuter VE, Voss MH, Motzer RJ, Coleman JA, et al. Clinical and pathologic impact of select chromatin-modulating tumor suppressors in clear cell renal cell carcinoma. Eur Urol. 2013;63:848-54.

22. Gossage L, Eisen T, Maher ER. VHL, the story of a tumour suppressor gene. Nat Rev Cancer. 2015;15:55-64.

23. Kim JH, Jung CW, Cho YH, Lee J, Lee SH, Kim HY, Park J, Park JO, Kim K, Kim WS, Park YS, Im Y-H, Kang WK, et al. Somatic VHL alteration and its impact on prognosis in patients with clear cell renal cell carcinoma. Oncol Rep. 2005;13:859-64. 
24. Schraml P, Struckmann K, Hatz F, Sonnet S, Kully C, Gasser T, Sauter G, Mihatsch MJ, Moch H. VHL mutations and their correlation with tumour cell proliferation, microvessel density, and patient prognosis in clear cell renal cell carcinoma. J Pathol. 2002;196:186-93.

25. The Cancer Genome Atlas Research Network. Comprehensive molecular characterization of clear cell renal cell carcinoma. Nature. 2013;499:43-9.

26. Brugarolas J. PBRM1 and BAP1 as novel targets for renal cell carcinoma. Cancer J Sudbury Mass. 2013;19:324-32.

27. del Puerto-Nevado L, Rojo F, Zazo S, Caramés C, Rubio G, Vega R, Chamizo C, Casado V, Martínez-Useros J, Rincón R, Rodríguez-Remírez M, Borrero-Palacios A, Cristóbal I, et al. Active angiogenesis in metastatic renal cell carcinoma predicts clinical benefit to sunitinib-based therapy. Br J Cancer. 2014;110:2700-7.

28. Paule B, Bastien L, Deslandes E, Cussenot O, Podgorniak M-P, Allory Y, Naïmi B, Porcher R, de La Taille A, Menashi $\mathrm{S}$, Calvo F, Mourah S. Soluble isoforms of vascular endothelial growth factor are predictors of response to sunitinib in metastatic renal cell carcinomas. PLoS One. 2010;5:e10715.

29. Garcia-Donas J, Leandro-Garcia LJ, Gonzalez del Alba A, Morente M, Alemany I, Esteban E, Arranz JA, Climent MA, Gallardo E, Castellano DE, Bellmunt J, Mellado B, Puente $\mathrm{J}$, et al. Prospective study assessing hypoxia-related proteins as markers for the outcome of treatment with sunitinib in advanced clear-cell renal cell carcinoma. Ann Oncol. 2013;24:2409-14.

30. Farace F, Gross-Goupil M, Tournay E, Taylor M, Vimond N, Jacques N, Billiot F, Mauguen A, Hill C, Escudier B. Levels of circulating CD45dimCD34+VEGFR2+ progenitor cells correlate with outcome in metastatic renal cell carcinoma patients treated with tyrosine kinase inhibitors. Br J Cancer. 2011;104:1144-50.

31. Scartozzi M, Bianconi M, Faloppi L, Loretelli C, Bittoni A, Del Prete M, Giampieri R, Maccaroni E, Nicoletti S, Burattini L, Minardi D, Muzzonigro G, Montironi R, et al. VEGF and VEGFR polymorphisms affect clinical outcome in advanced renal cell carcinoma patients receiving first-line sunitinib. Br J Cancer. 2013;108:1126-32.

32. Gámez-Pozo A, Antón-Aparicio LM, Bayona C, Borrega P, Gallegos Sancho MI, García-Domínguez R, de Portugal T, Ramos-Vázquez M, Pérez-Carrión R, Bolós MV, Madero R, Sánchez-Navarro I, Fresno Vara JA, et al. MicroRNA expression profiling of peripheral blood samples predicts resistance to first-line sunitinib in advanced renal cell carcinoma patients. Neoplasia. 2012;14:1144-52.

33. van der Veldt AA, Eechoute K, Gelderblom H, Gietema J, Guchelaar HJ, van Erp NP, van den Eertwegh AJ, Haanen JB, Mathijssen RH, Wessels JA. Genetic polymorphisms associated with a prolonged progression-free survival in patients with metastatic renal cell cancer treated with sunitinib. Clin Cancer Res. 2011;17:620-9.

34. Tierney JF, Stewart LA, Ghersi D, Burdett S, Sydes MR. Practical methods for incorporating summary time-to-event data into meta-analysis. Trials. 2007;8:16.

35. Parmar MK, Torri V, Stewart L. Extracting summary statistics to perform meta-analyses of the published literature for survival endpoints. Stat Med. 1998;17:2815-34.

36. Lau J, Ioannidis JP, Schmid CH. Quantitative synthesis in systematic reviews. Ann Intern Med. 1997;127:820-6. 